\title{
EFEK EKSTRAK ETANOL DAGING PUTIH SEMANGKA DAN SIMVASTATIN TERHADAP AKTIVASI NUCLEAR FACTOR KAPPA BETA (NF- kß) AORTA TIKUS RATTUS NORVEGICUS YANG DIBERI DIET ATEROGENIK
}

\author{
Dafrosi Darmi Manggasa \\ ${ }^{1}$ Program Studi Keperawatan Poso, Politeknik Kesehatan Kementerian Kesehatan Palu \\ Email: dafrosiamanggasa@gmail.com
}

\begin{abstract}
ABSTRAK
Diet aterogenik dapat menyebabkan kondisi dislipidemia yang memicu terjadinya peningkatan Reactive Oxygen Species (ROS) dan mengakibatkan stres oksidatif. Peningkatan ROS dapat mengaktifkan faktor transkripsi Nuclear Factor Kappa Beta (NF-k $\beta)$. NF-k $\beta$ yang teraktivasi akan menginduksi terbentuknya sitokin proinflamasi yang akan meningkatkan progresivitas aterosklerosis. Daging putih semangka terbukti memiliki senyawa antioksidan yang dapat menghambat ROS. Penelitian ini bertujuan untuk membuktikan efek ekstrak daging putih semangka dan simvastatin terhadap penurunan aktivasi NF-k $\beta$ tikus Rattus norvegicus yang diberi diet aterogenik. Penelitian eksperimental ini menggunakan Post Test Only Control Group Design. Sampel dibagi 5 kelompok yaitu (i) diet standar (K-), (ii) diet aterogenik $(\mathrm{K}+)$, (iii) diet aterogenik+ekstrak daging putih semangka $250 \mathrm{mg} / \mathrm{kgBB} / \mathrm{hari}$, (iv) diet aterogenik+ekstrak daging putih semangka dosis $500 \mathrm{mg} / \mathrm{kgBB} / \mathrm{hari}$ dan (v) diet aterogenik+simvastatin $0,9 \mathrm{mg} / \mathrm{kgBB} /$ hari. Aktivasi $\mathrm{NF}-\mathrm{k} \beta$ diukur menggunakan metode imunohistokimia. Data dianalisis dengan uji ANOVA dan uji post hoc. Hasil penelitian menunjukkan terdapat penurunan yang signifikan rerata aktivasi NF-k $\beta$ pada pemberian ekstrak daging putih semangka dosis $250 \mathrm{mg} / \mathrm{kgBB} / \mathrm{hari}(\mathrm{p}=0,000)$, dan dosis 500 $\mathrm{mg} / \mathrm{kgBB} / \mathrm{hari}(\mathrm{p}=0,000)$. Simvastatin $0,9 \mathrm{mg} / \mathrm{kgBB} / \mathrm{hari}$ juga menurunkan aktivasi NF-k $\beta$ secara signifikan $(\mathrm{p}=0,000)$ dibandingkan dengan kelompok diet aterogenik. Disimpulkan bahwa ekstrak daging putih semangka mempunyai efektifitas yang sama dengan simvastatin $0,9 \mathrm{mg} / \mathrm{kgBB} / \mathrm{hari}$ dalam menurunkan aktivasi NF-k $\beta$ pada tikus yang diberi diet aterogenik.
\end{abstract}

Kata kunci: daging putih semangka, simvastatin, NF-k $\beta$, diet aterogenik.

\begin{abstract}
Atherogenic diet can lead to dyslipidemia condition that trigger increase Reactive Oxygen Species (ROS) and oxidative stress. The increasing of ROS can activate transcription factor Nuclear Factor Kappa Beta (NF-k $\beta)$. Activated NF-k $\beta$ induce proinflammatory cytokines that will increase the atherosclerosis progressivity. Watermelon rind had proven to have antioxidant compounds that can inhibit ROS. This study was aimed to prove the effect of watermelon rind extract and simvastatin to decrease the NF-k $\beta$ aktivation of Rattus norvegicus with atherogenic diet. This research was using Post Test Only Control Group Design. The samples were divided into five groups: (i) standard diet (K(-)), (ii) atherogenic diet $(\mathrm{K}(+))$, (iii) atherogenic diet + watermelon rind extract $250 \mathrm{mg} / \mathrm{kgBW} / \mathrm{day}$, (iv) atherogenic diet + watermelon rind $500 \mathrm{mg} / \mathrm{kgBW} /$ day, and (v) the atherogenic diet + simvastatin $0.9 \mathrm{mg} / \mathrm{kgBW} / \mathrm{day}$. Atherogenic diet was given for 8 weeks. NF-k $\beta$ were measured by immunohistochemistry. Data were analyzed with ANOVA and post hoc test. The results showed a significant decrease mean NF-k $\beta$ activation after treatment of watermelon rind extract of $250 \mathrm{mg} / \mathrm{kg} / \mathrm{day}(\mathrm{p}=0,000)$, dose of $500 \mathrm{mg} / \mathrm{kg} / \mathrm{day}(\mathrm{p}=0.000)$, and
\end{abstract}


simvastatin dose of $0.9 \mathrm{mg} / \mathrm{kg} /$ day could reduced NF-k $\beta$ significantly $(\mathrm{p}=0,000)$ compared with atherogenic diet group. It concluded that the watermelon rind extract dose 500 $\mathrm{mg} / \mathrm{kgBW} /$ day was equivalent to simvastatin $0,9 \mathrm{mg} / \mathrm{kgBW} /$ day in lowering the $\mathrm{NF}-\mathrm{k} \beta$ activation rats with atherogenic diet.

Keywords: watermelon rind, simvastatin, NF-k及, atherogenic diet.

\section{PENDAHULUAN}

Penyakit kardiovaskuler seperti infark miokard, gagal jantung, dan stroke merupakan masalah kesehatan yang dihadapi oleh negara maju maupun negara berkembang. Penyebab terbanyak penyakit kardiovaskuler adalah aterosklerosis. Jumlah kematian akibat aterosklerosis lebih besar jika dibandingkan dengan jumlah kematian akibat kanker. Diperkirakan sekitar 17,1 juta orang (29\%) dari jumlah seluruh kematian di dunia meninggal karena aterosklerosis. Pada tahun 2030, diperkirakan hampir 23,6 juta orang akan meninggal karena aterosklerosis. $^{1} \quad$ Berdasarkan Riset Kesehatan Dasar (Riskesdas) 2013, prevalensi penyakit jantung koroner berdasarkan wawancara terdiagnosis dokter di Indonesia sebesar 0,5 persen. Penderita lainnya terdiagnosis dokter atau gejala sebesar 1,5 persen. $^{2}$

Aterosklerosis diawali oleh terjadinya disfungsi endotel pembuluh darah. Endotel merupakan lapisan terdalam pembuluh darah yang berfungsi menjaga dinding pembuluh darah dan fungsi sirkulasi. Disfungsi endotel akan cenderung menyebabkan kondisi vasokonstriksi, aterogenik dan proinflamasi. $^{3} \quad$ Salah satu faktor risiko yang berkontribusi pada patogenesis ini adalah dislipidemia yang memicu peningkatan Reactive Oxygen Species (ROS). Literatur menunjukkan bahwa faktor risiko dan peningkatan ROS dapat menyebabkan disfungsi endotel. ${ }^{4}$

Diet aterogenik dapat menyebabkan kondisi dislipidemi yang memicu terjadinya LDL teroksidasi (OxLDL). OxLDL merangsang terbentuknya Reactive Oxygen Species (ROS) pada pembuluh darah yang menyebabkan terjadinya reaksi inflamasi dan dapat berakibat pada perubahan dinding pembuluh darah. ${ }^{5}$ Inflamasi memiliki peran yang penting pada kejadian penyakit jantung koroner (PJK) dan beberapa manifestasi aterosklerosis lainnya. Dominasi sel-sel imun akan mengawali pembentukan lesi aterosklerosis. Peningkatan ROS dapat mengaktifkan faktor transkripsi Nuclear Factor Kappa Beta $(\mathrm{NF}-\mathrm{k} \beta)$. NF-k $\beta$ yang teraktivasi akan menginduksi terbentuknya sitokin proinflamasi (TNF- $\alpha$, IL-1) serta 
molekul/zat perantara lainnya (VCAM-1, ICAM-1) yang pada akhirnya meningkatkan progresifitas aterosklerosis. ${ }^{6}$ $\mathrm{NF}-\mathrm{k} \beta$ terlibat dalam patogenesis aterosklerosis maka NF-k $\beta$ dapat menjadi target terapi dalam menghambat perkembangan aterosklerosis. ${ }^{7}$

Pengobatan yang sering dilakukan untuk menghambat proses aterogenesis salah satunya adalah dengan penggunaan statin diantaranya yang sering dikonsumsi masyarakat adalah simvastatin, namun penggunaan statin dalam jangka panjang dilaporkan memiliki efek samping berupa miopati dan gagal ginjal, sehingga pemakaian obat ini tetap harus dalam pengawasan. ${ }^{8}$ Masyarakat dapat memanfaatkan bahan alami sebagai alternatif untuk mengobati penyakit gangguan metabolik. ${ }^{9}$ Salah satu bahan yang dapat mencegah progresivitas aterosklerosis adalah antioksidan yang dapat diperoleh dari sayur dan buah. Buah semangka merupakan salah satu buah yang banyak dikonsumsi masyarakat serta mudah diperoleh, namun kebanyakan masyarakat hanya mengkonsumsi daging buah yang berwarna mencolok (misalnya merah, merah muda, dan kuning), masih sedikit masyarakat yang mengetahui manfaat dari daging putih semangka sehingga bagian tersebut hanya menjadi limbah tanpa dimanfaatkan. Ekstrak buah semangka telah dibuktikan dapat menurunkan konsentrasi kolesterol plasma, menurunkan sitokin proinflamasi dan mencegah perkembangan aterosklerosis pada tikus dislipidemi. ${ }^{10}$ Penelitian menunjukkan bahwa daging putih dari semangka mengandung golongan senyawa flavonoid dan steroid/triterpenoid. ${ }^{11}$ Penelitian Ismayanti., et al (2013) juga menemukan kadar Fenolat sebesar 18,702 $\mathrm{mg} / \mathrm{g}$ dan memiliki aktivitas antioksidan dalam jus kulit buah semangka bulat. ${ }^{12}$

Berdasarkan hal tersebut, tujuan penelitian ini adalah untuk membuktikan efek dari pemberian ekstrak etanol daging putih semangka dan simvastatin dalam menurunkan aktivasi NF-k $\beta$ aorta tikus putih Rattus norvegicus yang diberi diet aterogenik.

\section{METODE PENELITIAN}

\section{Desain Penelitian}

Penelitian ini merupakan penelitian eksperimental dengan rancangan post test control group design dengan menggunakan 25 ekor tikus putih (Rattus Norvegicus) galur wistar. Hewan coba dipelihara di Laboratorium Farmakalogi Fakultas Kedokteran Universitas Brawijaya Malang dan penelitian ini mendapatkan persetujuan laik etik dari Komisi Etik Penelitian Kesehatan Fakultas Kedokteran Universitas Brawijaya Malang Indonesia (No: 153/EC/KEPK/S2/04/2016). 
Hewan coba terlebih dahulu diaklimatisasi (adaptasi) selama tujuh hari serta diberikan makan dan minum secara ad libitum. Semua tikus dibagi menjadi 5 kelompok secara random yang terdiri atas (i) kelompok tikus yang diberi diet standar $(\mathrm{K}(-))$, (ii) tikus diberi diet aterogenik $(\mathrm{K}(\mathrm{P})$ ), (iii) tikus diberi diet aterogenik (DA)+ekstrak daging putih semangka (EDPS) $250 \mathrm{mg} / \mathrm{kgBB} / \mathrm{hari}$ (P1), (iv) tikus diberi diet aterogenik+ekstrak daging putih semangka $500 \mathrm{mg} / \mathrm{kgBB} / \mathrm{hari}$ (P2) dan tikus diberi diet aterogenik+simvastatin 0,9 $\mathrm{mg} / \mathrm{kgBB} /$ hari (P3). Diet tinggi lemak diberikan selama 8 minggu. ${ }^{13}$

\section{Pembuatan Pakan Tikus}

Bahan diet standar terdiri atas Comfeed PARS $66,67 \%$ (dengan kandungan air $12 \%$, protein $11 \%$, lemak $4 \%$, serat $7 \%$, abu $8 \%$, Ca $1,1 \%$, fosfor 0,9\%, antibiotik coccidiostat 53\%) dan air $33,33 \%$. Diet aterogenik terdiri atas Comfeed PARS 50\%, tepung terigu $25 \%$, kolesterol $2 \%$, asam kolat $0,2 \%$, minyak babi $5 \%$, dan air $17,8 \% .^{13}$

\section{Pembuatan Ekstrak Daging Putih Semangka}

Semangka dicuci, dikupas, dipisahkan antara daging berwarna merah dan putih kemudian daging putih semangka diambil, dipotong kecil-kecil dan dikeringkan menggunakan oven dengan suhu $80^{\circ} \mathrm{C}$. Sampel kering kemudian diekstraksi dengan larutan etanol. Ekstrak etanol daging putih semangka ini diencerkan dengan aquadest sesuai dosis yang dibutuhkan dan diberikan menggunakan sonde oral ke subjek penelitian sesuai kelompoknya setiap hari.

Pemeriksaan Aktivasi NF-k $\beta$ dengan Metode Immunohistokimia

Pembuatan preparat aorta tikus melalui proses fiksasi, embedding dan penyayatan kemudian dilakukan pewarnaan imunohistokimia menggunakan monoclonal anti p50 sebagai antibodi primer NF-k $\beta$ (Santa Cruz, nomor katalog sc-114) untuk mengetahui perpindahan komplek p50-p65 (dimer NFkB) dari sitoplasma ke inti sel kemudian diamati dengan mikroskop dengan pembesaran 1000x pada 20 lapangan pandang yang berbeda, diulangi 5 kali. Pada pengecatan imunohistokimia, warna coklat pada inti sel endotel jaringan aorta, menandakan NF-k $\beta$ yang teraktivasi dan warna ungu pada inti sel endotel jaringan aorta menandakan intisel yang tidak teraktivasi.

\section{Analisis Data}

Data dianalisis menggunakan one way ANOVA serta uji post hoc untuk mengetahui perbedaan perlakuan yang diberikan. Uji statistik dilakukan pada derajat kepercayaan 95\% dengan $\alpha=0,05$. 


\section{HASIL DAN PEMBAHASAN}

Tabel 1. Rerata Aktivasi NF-kß Pada Berbagai Kelompok Perlakuan

\begin{tabular}{lrlc}
\hline \multicolumn{1}{c}{ Perlakuan } & Rerata (\%) & & \\
Simpang Baku & Nilai-p \\
\hline Diet standar & $27,452 \pm 1,01$ & a & \\
Diet aterogenik & $49,742 \pm 1,706$ & c & \\
DA + EDPS $250 \mathrm{mg} / \mathrm{kgBB} / \mathrm{hari}$ & $31,024 \pm 0,59$ & $\mathrm{~b}$ & 0,000 \\
DA + EDPS $500 \mathrm{mg} / \mathrm{kgBB} / \mathrm{hari}$ & $28,088 \pm 1,289$ & a & \\
DA + Simvastatin 0,9 mg/kgBB/hari & $29,123 \pm 1,81$ & a & \\
\hline
\end{tabular}

Keterangan: Pada rata-rata \pm sd jika memuat huruf yang berbeda berarti ada perbedaan yang bermakna $(p<0,05)$ dan jika memuat huruf yang sama berarti tidak ada perbedaan yang bermakna $(p>0,05)$.

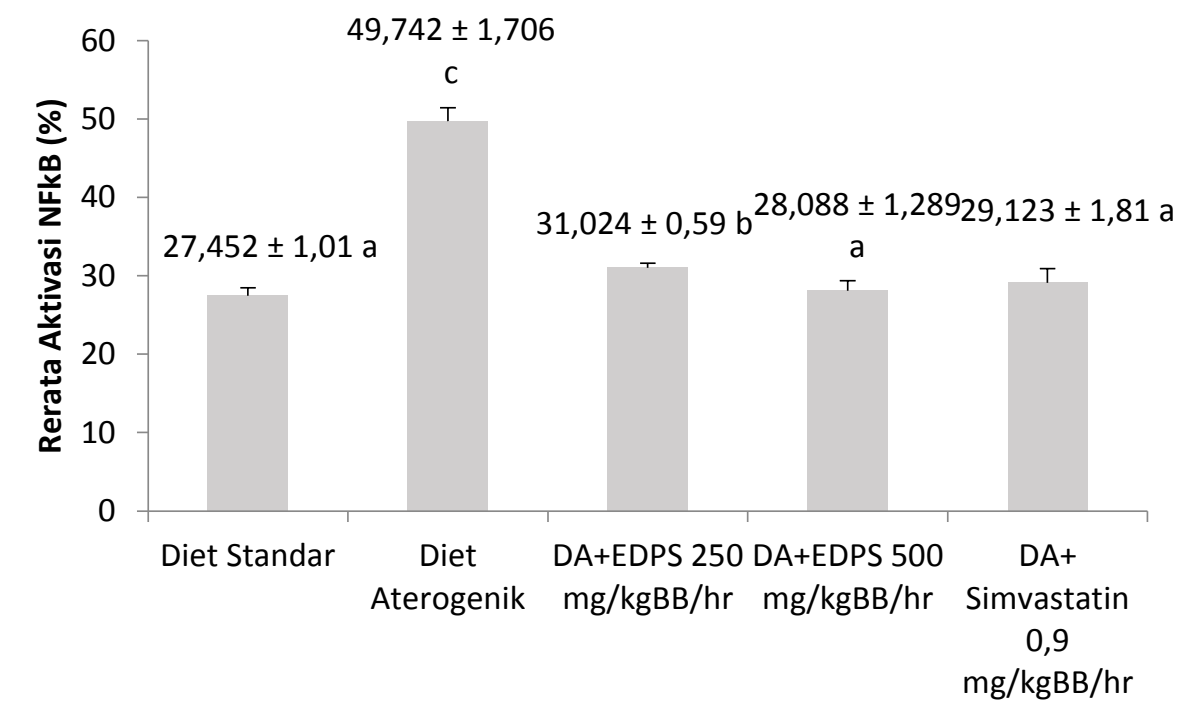

Gambar 1. Histogram Rerata Aktivasi NF-kß

Berdasarkan pada hasil analisis dengan menggunakan ANOVA, didapatkan nilai-p sebesar 0,000, lebih kecil daripada $\alpha=0,05(\mathrm{p}<0,05)$, sehingga dari pengujian ini dapat disimpulkan bahwa terdapat perbedaan yang signifikan aktivasi NF-k $\beta$ antar kelompok perlakuan. Untuk mengetahui kelompok mana yang berbeda secara signifikan maka dilanjutkan dengan uji post hoc menggunakan uji LSD.
Berdasarkan pada hasil uji LSD didapatkan bahwa aktivasi NF-k $\beta$ pada kelompok diet aterogenik meningkat secara signifikan dibandingkan dengan kelompok diet standar $(\mathrm{p}=0,000)$. Pada kelompok diet aterogenik + ekstrak daging putih semangka dosis $250 \mathrm{mg} / \mathrm{kgBB} / \mathrm{hari}$ didapatkan penurunan aktivasi NF-k $\beta$ secara signifikan dibandingkan kelompok diet aterogenik $(\mathrm{p}=0,000)$ dan jika dibandingkan dengan kelompok diet 
standar aktivasi NF-k $\beta$ lebih tinggi secara signifikan $(\mathrm{p}=0,000)$. Pada kelompok diet aterogenik + ekstrak daging putih semangka $500 \mathrm{mg} / \mathrm{kgBB} / \mathrm{hari}$ didapatkan aktivasi NF-k $\beta$ menurun secara signifikan dibandingkan kelompok diet aterogenik $(0,000)$ dan jika dibandingkan dengan kelompok diet standar didapatkan aktivasi NF-k $\beta$ tidak berbeda signifikan $(p=0,459)$ yang berarti bahwa pemberian ekstrak daging putih semangka dosis 500 $\mathrm{mg} / \mathrm{kgBB}$ mampu menurunkan aktivasi NF-k $\beta$ mendekati kondisi normal/sehat. Pada kelompok diet aterogenik + simvastatin $0,9 \mathrm{mg} / \mathrm{kgBB} /$ hari didapatkan aktivasi NF-k $\beta$ yang menurun secara signifikan dibandingkan dengan kelompok diet aterogenik $(p=0,000)$ dan tidak terdapat perbedaan yang signifikan jika dibandingkan dengan kelompok diet standar $(p=0,076)$ yang berarti bahwa pemberian simvastatin dosis $0,9 \mathrm{mg} / \mathrm{kgBB}$ mampu menurunkan aktivasi NF-k $\beta$ mendekati kondisi normal.

Pada perbandingan kelompok diet aterogenik+ekstrak daging putih semangka dosis $500 \mathrm{mg} / \mathrm{kgBB} /$ hari dengan kelompok diet aterogenik + simvastatin 0,9 $\mathrm{mg} / \mathrm{kgBB} / \mathrm{hari}$ tidak terdapat perbedaan yang signifikan (nilai-p >0,05), hal ini menunjukkan bahwa pemberian ekstrak daging putih semangka dosis 500 $\mathrm{mg} / \mathrm{kgBB} / \mathrm{hari}$ memiliki efektifitas yang sama dengan simvastatin dalam menurunkan aktivasi NF-k $\beta$.

Tabel 2. Hasil Analisis Regresi Aktivasi NF-kß

\begin{tabular}{ccccc}
\hline $\begin{array}{c}\text { Variabel } \\
\text { Terikat }\end{array}$ & Persamaan Regresi & Nilai-p & $\begin{array}{c}\text { Korelasi } \\
\text { Nilai-p }\end{array}$ & $\begin{array}{c}\text { R- } \\
\text { Square }\end{array}$ \\
\hline NF-k $\beta$ & $Y=47,112-0,043 \mathrm{X}$ & 0,000 & $\mathrm{r}=-0,915$ & \\
\hline $\begin{array}{l}\text { Dimana : }=0,000 \\
\text { Y : Aktivasi NF-k } \beta\end{array}$ & $83,76 \%$ \\
X : Konsentrasi Ekstrak Daging Putih Semangka & & \\
\end{tabular}

Berdasarkan hasil analisis korelasi dan regresi didapatkan koefisien korelasi sebesar -0,915 menunjukkan adanya hubungan yang sangat kuat antara dosis ekstrak daging putih semangka dengan aktivasi NF-k $\beta$. Koefisien korelasi bertanda negatif menjelaskan bahwa peningkatan dosis akan berdampak pada penurunan aktivasi NF-k $\beta$ atau dengan kata lain semakin tinggi dosis maka aktivasi NF-k $\beta$ akan semakin menurun. Koefisien determinasi (R-square) sebesar 83,76\% menunjukkan bahwa pemberian Ekstrak Daging Putih Semangka mampu mempengaruhi penurunan aktivasi NF-k $\beta$ sebesar $83,76 \%$. Sisanya sebesar $16,24 \%$ 
dijelaskan oleh faktor lain yang tidak terlibat dalam penelitian.

Pemberian diet aterogenik bertujuan untuk membuat terjadinya kondisi dislipidemi pada kelompok perlakuan. Penelitian pada tikus percobaan dapat menginduksi kondisi dislipidemi dengan cara pemberian pakan yang ditambah kolesterol 2\%, minyak babi 5\%, dan asam kolat $0,2 \%$. Pemberian pakan ini selama 8 minggu dapat meningkatkan kolesterol darah dan menginduksi terbentuknya foam cell secara bermakna. ${ }^{13}$ Dislipidemi menyebabkan terjadinya peningkatan ROS yang memicu kerusakan jaringan dan penurunan produksi dan bioavailibilitas dari NO yang kemudian disebut disfungsi endotel. Disfungsi endotel memicu penumpukan LDL teroksidasi di tunika intima. Penumpukan LDL teroksidasi menyebabkan peningkatan ROS yang diperparah oleh makrofag dan sel otot polos. Hal ini menyebabkan vasokonstriksi, agregasi platelet, dan adesi neutrophil ke endotelium. Peningkatan OxLDL di lapisan tunika intima menyebabkan penumpukan sel busa dan akan menjadi plak aterosklerosis. ${ }^{14}$ Penelitian ini menunjukkan pada kelompok tikus yang diberi diet aterogenik terjadi peningkatan aktivasi NF-k $\beta$ yang lebih tinggi dibanding kelompok yang diberi diet standar. Peningkatan tersebut disebabkan oleh pemberian diet aterogenik yang mengakibatkan terjadinya OxLDL. OxLDL merangsang terbentuknya Reactive Oxygen Species (ROS). Selanjutnya ROS akan mengakibatkan aktivasi NF-k $\beta$. Penelitian Rohman, et al (2006) membuktikan bahwa Pemberian OxLDL pada sel endotel mengakibatkan perpindahan sebagian besar dimer p50-p65 $(\mathrm{NF}-\mathrm{k} \beta)$ dari sitoplasma ke inti sel. OxLDL mengaktifkan NF-k $\beta$ dengan cara perpindahan $\mathrm{NF}-\mathrm{k} \beta$ dari sitoplasma ke inti melalui pembentukan ROS yang berlebihan. ${ }^{15}$

Pada penelitian ini telah dibuktikan bahwa terjadi penurunan yang signifikan aktivasi NF-k $\beta$ pada kelompok perlakuan yang diberi diet aterogenik+ekstrak daging putih semangka dosis $250 \mathrm{mg} / \mathrm{kgBB}$ dan dosis $500 \mathrm{mg} / \mathrm{kgBB} /$ hari. Hasil uji korelasi didapatkan koefisien korelasi sebesar 0,915 yang menunjukkan adanya hubungan yang sangat kuat antara dosis dengan aktivasi NF-k $\beta$. Semakin tinggi dosis ekstrak daging putih semangka maka aktivasi NF-k $\beta$ semakin menurun. Penurunan NF-k $\beta$ juga ditunjukkan pada kelompok yang diberi diet aterogenik+simvastatin $0,9 \mathrm{mg} / \mathrm{kgBB} /$ hari. Menurut Grune (2005) simvastatin merupakan golongan statin yang dapat digunakan sebagai antioksidan. Mekanisme antioksidan dari golongan statin ini adalah dengan menghambat 
pembentukan oksidan dengan juga dapat menghambat TNF- $\alpha$ dan mempengaruhi NADPH oksidase, memblokir efek dari ROS sebagai antioksidan, atau peningkatan oksidan nitrat yang menetralkan radikal ROS, termasuk radikal bebas seperti radikal anion superoksida, hidroksil dan hidrogen peroksida. ${ }^{16}$

Pada sel yang tidak terstimulasi, NF-k $\beta$ berada di sitoplasma dan berinteraksi dengan $\mathrm{I} k$-B. Stimulus dapat mengaktifkan $\mathrm{I} k$-B kinase yang dapat memfosforilasi $\quad \mathrm{I} k \mathrm{~B}, \quad$ sehingga $\quad \mathrm{I} k \mathrm{~B}$ mengalami degradasi dan translokasi NF$\mathrm{k} \beta$ pada nukleus. Pada nukleus, NF-k $\beta$ berikatan dengan target gen dan menstimulasi terjadinya transkripsi dari mediator inflamasi seperti TNF- $\alpha$, IL- $1 \beta$, IL-6. Flavonoid berperan sebagai antioksidan dan antiinflamasi. Flavonoid mempunyai kecenderungan mengikat atom, atau sebagai scavenger bagi radikal bebas, sehingga tidak terbentuk ROS berlebihan. Apabila pembentukan ROS dihambat oleh zat aktif flavonoid yang terkandung dalam daging putih semangka, maka aktivasi NF-k $\beta$ pun dapat dihambat sehingga terjadi penurunan aktivasi dari NF-k $\beta$. Hambatan pada aktivasi NF-k $\beta$ dapat mencegah progresivitas aterosklerosis. Penelitian Kamiya (2004) membuktikan bahwa zat bioaktif flavonoid yang terkandung dalam buah mengkudu terbukti menghambat aktivasi NF-k $\beta$, dan ICAM-1 HUVECs yang dipapar LDL teroksidasi. ${ }^{17}$

Penurunan tersebut menunjukkan terdapat peran flavonoid yang terkandung dalam esktrak daging putih semangka terhadap hambatan pada aktivasi NF-k $\beta$. Hal ini membuktikan bahwa flavonoid dalam ekstrak daging putih semangka sebagai antioksidan merupakan scavenger ROS yang akan menghambat reaksi oksidasi dari LDL. Penurunan oksidasi LDL akan menghambat aktivasi NF-k $\beta$, sehingga terjadi penurunan kadar TNF- $\alpha$ dalam sirkulasi. Flavonoid juga berperan sebagai antiinflamasi yang dapat menghambat aktivasi NF-k $\beta$ dengan penghambatan degradasi $\operatorname{Ik} \beta$ dan terjadinya fosforilase. Akibatnya dimer dari NF-k $\beta$ (p50 dan p65) tidak terlepas dan selanjutnya tidak terjadi translokasi p50 dan p65 ke dalam nuklues. Dengan penurunan aktivasi NF-k $\beta$ maka transkripsi gen inflamatori TNF- $\alpha$ menjadi turun. NF$\mathrm{k} \beta$ merupakan faktor transkripsi sel yang dapat mengontrol ekspresi beberapa gen termasuk TNF- $\alpha$ dan IL-1. ${ }^{18}$

Pada penelitian ini pemberian ekstrak daging putih semangka pada tikus ternyata mampu menurunkan aktivasi NF$\mathrm{k} \beta$ pada tikus yang diberi diet aterogenik demikian juga dengan simvastatin dosis 0,9 $\mathrm{m} / \mathrm{kgBB} / \mathrm{hari}$ mampu menurunkan aktivasi NF-k $\beta$. Pada aktivasi NF-k $\beta$ baik 
ekstrak daging putih semangka maupun simvastatin mampu menurunkan aktivasi NF-k $\beta$ kembali normal dengan demikian ekstrak daging putih semangka mempunyai

\section{KESIMPULAN DAN SARAN}

Pemberian ekstrak daging putih semangka dosis 250 dan 500 $\mathrm{mg} / \mathrm{kgBB} / \mathrm{hari}$, juga simvastatin 0,9 $\mathrm{mg} / \mathrm{kgBB} /$ hari dapat menurunkan aktivasi NF-k $\beta$ aorta tikus putih (Rattus norvegicus) yang diberi aterogenik secara signifikan dan ekstrak daging putih semangka dosis $500 \mathrm{mg} / \mathrm{kgBB} / \mathrm{hari}$ mempunyai efektifitas yang sama dengan simvastatin $0,9 \mathrm{mg} / \mathrm{KgBB} / \mathrm{hari}$ dalam

\section{DAFTAR PUSTAKA}

1. WHO 2011. Global atlas on cardiovascular disease prevention and control. Published by WHO in collaboration with the world heart federation and the world stroke organization.

(online)

http://www.world-heart-federation.org [diakses 29 Oktober 2015].

2. Riset Kesehatan Dasar (Riskesdas). 2013. Badan Penelitian Dan Pengembangan Kesehatan Kementerian Kesehatan RI. Jakarta. (Online) http://www.depkes.go.id [diakses 16 Mei 2015].

3. Galley HF and Webster NR. 2004. Physiology of The Endothelium. efektifitas yang sama dengan simvastatin dalam menurunkan aktivasi NF-k $\beta$ pada tikus yang diberi diet aterogenik.

menurunkan aktivasi NF-k $\beta$ aorta tikus putih (Rattus norvegicus) yang diberi diet aterogenik. Saran pada penelitian ini adalah sebaiknya dilakukan penelitian lebih lanjut untuk menyelidiki jenis flavonoid yang terkandung dalam daging putih semangka, dan perlu dilakukan uji klinis terhadap ekstrak daging putih semangka untuk dapat digunakan sebagai obat/fitofarmaka pada manusia.

British Journal of Anaesthesia; 93(1):105-13

4. Papaharalambus $\mathrm{AC}$ and Griendling KK. 2007. Basic Mechanism of Oxidative Stress And Reactive Oxygen Species In Cardiovascular Injury. Trends in Cardiovascular Medicine; 17(2):48-54.

5. Murray RK, Granner DK, Mayes PA, Rodwell VW. 2009. Biokimia Harper. Jakarta: EGC

6. Collins T and Cybulsky MI. 2001. NF$k B$ : Pitoval Mediator or Innocent Bystander In Atherogenesis ?. The Jounal of Clinical Investigation; 107(3): 255-263. 
7. Krause BR, Auerbach BJ, Bocan TMA. 2001. Direct Vascular Target for Atherosclerosis Prevention. Current Medicinal ChemistryImmunology, Endocrine \& Metabolic Agents; 1(1): 39-46.

8. Grundy. 2005. The Issue of Statin Safety: Where Do We Stand?. Circulation; 111:3016-3019.

9. Dennis DL, Beaunwald E, Hauser S, Longo D, Jameson JL, Anthony SF. 2005. Harrison's Principles of Internal Medicine. 16th edition. New York: Mc Graw Hill.

10. Poduri A, Debra L, Rateri, Shubin K, Saha, Sibu S, Daugherty A. 2013. Citrullus lanatus 'Sentinel' (Watermelon) Extract Reduces Atherosclerosis in LDL Receptor Deficient Mice. The Journal of Nutritional Biochemistry; 24(5): 882886.

11. Listiane S. 2008. Telaah Kandungan Kimia Bagian Putih Dari Buah Semangka (Citrullus Vulgaris Linn). (Online). $\quad$ http://digilib.itb.ac.id [diakses 2 April 2015].

12. Ismayanti, Bahri S, Nurhaeni. 2013. Kajian Kadar Fenolat Dan Aktivitas Antiosidan Jus Kulit Buah Semangka (Citrullus lanatus). Online Jurnal of Natural Science; 2(3): 100-110

13. Murwani S, Mulyohadi A, Muliartha K. 2006. Diet Aterogenik Pada Tikus
Putih (Rattus Novergicus Strain Wistar) Sebagai Model Hewan Aterosklerosis. Jurnal Kedokteran Brawijaya; 22(1): 6-12.

14. Vogiatzi G, Tousouli D, Stefanadis C. 2009. The Role of Oxidative Stress in Atherosclerosis. Hellenic Journal of Cardiology; 50(5): 402-409.

15. Rohman MS, Rastini EK, Sarbini D, Titin AW, Widodo, Sargowo D. 2006. Penghambatan Aktifasi NFk $\beta$ Ooeh Cape (Caffeic Acid Phenethyl Ester), Komponen Aktif Madu Lebah (Honeybee Hives), Pada Huvec's (Human Umbilical Vein Endothelial Cells) Yang Dipapar LDL Teroksidasi. Jurnal Kedokteran Brawijaya; 22(1): $1-5$.

16. Grune T. 2005. Free Radicals and Diseases: Gene Expression, Cellular Metabolism and Pathophysiology, Amsterdam: IOS Press.

17. Kamiya KY, Tanaka H, Endang M, Umar T, Satake. 2004. Chemical Constituent of Morinda Fruits Inhibit Cooper-induced Low Density Lipoprotein Oxidation. Journal of Agriculture and Food Chemistry; 52(19): 5843-5848.

18. Sargowo D, Senorita A, Widodo A. 2010. Peranan Ekstrak Kulit Manggis Dalam Penurunan Kadar TNF- $\alpha$ dan IL-1 Pada dyslipidemia. Malang: Universitas Brawijaya 